\title{
Exploring Registers Used by the Teachers of Mentally Retarded Students to Further Create a Dictionary
}

\author{
Noer DoddyIrmawati $^{1 *}$, Kasiyarno ${ }^{1}$, Pramugara Robiana ${ }^{2}$,Marilou D. Tino ${ }^{3}$ \\ ${ }^{1}$ Universitas Ahmad Dahlan (UAD) Yogyakarta, Indonesia \\ ${ }^{2}$ UniversitiTun Hussain Onn Malaysia (UTHM) Johor, Malaysia \\ ${ }^{3}$ University of Saint Anthony (USANT), Philippines
}

\author{
*Corresponding Author: Noer DoddyIrmawati, Universitas Ahmad Dahlan (UAD) Yogyakarta, \\ Indonesia
}

\begin{abstract}
People use different kinds of language when they express their ideas, thoughts, or feelings to communicate in certain situations. The languages used in the society are varies, especially in different fields. So, language that is used based on what is being done and the nature of speakers' activities. It aims to analyse and identify registers in the Teaching Learning Process (TLP) in exceptional schools for students with mental retardation. It sought to find out: if the teachers use registers in TLP; the meaning of register used by the teachers; and; look into the purpose of using registers in TLP who experience mental retardation. This was a qualitative research, the data were collected through observation, structured interviews, and documentation. Data analysis was carried out by data reduction, data presentation, and data inference. Analytical Research was used. The findings were based on the result of the data given by the teachers. The result found:1) mentally disabled students found it difficult to learn. It was caused by their mental retardation; 2) Intervention steps were needed to increase students' mastery in learning. Register dictionary was one of the best interventions for action besides the use of audio-visual material that was supported by technology.
\end{abstract}

Keywords: Registers, Teachers, Mentally Retardation, interventions.

\section{INTRODUCTION}

\subsection{Background}

Starting from the researchers' concern when seeing children who have special needs and mental disabilities in learning, especially learning languages, the researcher is interested in doing research about registers as part of linguistics that is not often realized but often used as a teaching and learning tool. That is why the title of the research: "Exploring Registers Used by The Teachers of Mentally Retarded Students to Further Create a Dictionary" needs to be proven, known, discussed and beard out that registers are important.

Register is defined as the way a speaker uses language differently indifferent circumstances. According to Wardhaugh (1992:49) Register is another complicating factor in any study of language varieties. Register is defined as sets of vocabulary items associated with discrete occupational or social groups. They might be same on its phonology and morphology forms but have different meaning based on its field and context. Such factors like: social occasion, context, purpose, and audience determine the Register. Registers are marked by a variety of specialized vocabulary and turns of phrases, colloquialisms, the use of jargon, and a difference in intonation and pace.

\subsection{Dimensions of Register}

According to Hudson (1991:49) there are three dimensions of register namely, field, mode, and tenor as follow:

\subsubsection{Field}

It is concerned with the purpose and subject matters of communication. For instance, political talk, health service; it is particularly affected by field. 


\subsubsection{Mode}

It refers to the means by which communication take a place, notably by speech or writing; spoken or written form as its medium of transmission.

1.2.3. Tenor

It relates to relation between the participants. It is the relationship between sender and receiver. It depends on who is taking part in the discourse.

\subsection{The Form of Register}

In this research, analysing and differentiating the register data on word and phrase form will be focused on.

\subsubsection{Word}

Procter (2008: 10) defines word as a single unit of language which has meaning and can be spoken or written. As Katamba(1993:17)said in his book, the term word is used in variety of sense which usually is not clearly distinguished. Yet we can assume that the word as the smallest form that can occur by itself as an utteranceas it can also be manipulated by syntax such as what occurred insentence structure of an active sentence and passive sentence.

\subsubsection{Phrase}

According to Procter (2008:11) phrase is defined as a group of words which is part rather than the whole of a sentence or a short group of words which are often used together and have a particular meaning. Phrase is merger of two or more word which can construct new meaning. Then, a phrase is a group of words that act as a part of speech but cannot stand alone as a sentence.

\subsection{Problem}

- Do teachers use registers in teaching language to mentally retarded students?

- How to apply these registers in language learning for mentally retarded students?

\section{LITERARY STUDY}

This study uses some theories given by experts to give a clear understanding of the study. Their view of related literature is used for guidance in conducting the research.

\subsection{Sociolinguistics}

According to Wardhaugh (1992: 13) Sociolinguistics is concerned with investigating the relationships between language and society with the goal being a better understanding of the structure of language and of how languages function in communication.

The term Sociolinguistics is used for the study of the relationship between language and society. This is an interdisciplinary field of study or research which developed through the interaction of linguistics with a number of other academic disciplines (Yule, 2006:205). It has strong connections with culture through the study of language and with sociology and the study of the role language plays in the formation of social groups and institutions.

\subsection{Language Variety}

Language variety is specific language or specific form of language used by a particular community. Wardhaugh(1992:22) defines language variety as follows: A set of linguistic items with similar distribution, a definition that allows us to say that all of the following are varieties: English, French, London English, the English of football commentaries, and English for News, English for Speech, English for Reporters. It means that, language variety refers to any distinguishable form of speech used by a speaker or group or speakers.

Sociolinguists differentiate a set of types of variation that covers most factors for language variation. The most general distinction is that between variation in the individual, called as idiolects; variation related to social factors, called as sociolects; regional variation, called as dialects and variation due to functional aspects, so-called registers or styles.

\subsection{The Concept of Mental Retardation Students}

According to Wantah(2007:15)children of mild mental retardations are children who have limitations to follow the learning in regular school but they still have the potential that can be developed such as 
the ability to take care of themselves, reading, writing, and simple counting and skill giving. Muhammad Efendi(2006:90)also states: "Mild mentally retarded students is unable to follow the regular school programs but still have the ability that can be developed through education, although not maximum. The abilities that can be developed in children with mild mental retardation include in: (1) reading, writing, spelling, and arithmetic; (2) adjusting and not depending on others; (3) simple skills for future work interests". From the statement above, it can be inferred that children with special needs still have a chance in learning. Since they need special treatment and attention.

\subsection{Mental Retarded Teaching}

Montessorias cited in Hainstock (2002:27) states that children (and also mentally retarded students) learning process need supporting environment that supports the adaptation and learning style of the children. The environment has some aspects such as accessibility and availability, freedom of movement and choice, personal responsibility, reality, nature, beauty and harmony. Much attention has been given to the proposition that the teacher-child relationship is critical to the teaching process, suggesting the importance of not only the "how" of teaching, but the relationship that develops between the teacher, on the one hand, and both individual children and the total group, on the other (Rosenthal\&Jacobson, 1966:117).Hence, the teachers should be able to manage proper situation in the classroom both technique and the language in teaching.

\section{OBJECTIVES AND BENEFITS OF RESEARCH}

\subsection{Objectives of the Research}

The learning process for the mentally disabled is aimed at self-development and socialization, developing students 'academic ability optimally to be independent in life, preparing learners to have the basics of intelligence, knowledge, characters, and noble character, providing learners to continue the education level further, preparing learners to socialize in the community. In the teaching and learning process, the teachers should have specific methods or techniques different with the normal students include language they used when explaining in order to make them easier in comprehend the learning materials. Hence, this study is conducted to explore the using of registers by teachers of mentally retarded students. This study has two mainly objectives:

- Do teachers use registers in teaching language to mentally retarded students?

- How to apply these registers in teaching learning process for mentally retarded students?

\subsection{The Benefit of the Research}

This research is benefit because it can be the umbrella of some other topics that can be conducted by the students of English Education Magister Program of Universitas Ahmad Dahlan Yogyakarta. There are two topics, entitled: The application of Registers on the Jakarta Globe online Newspaper which will be done by KentikaWulandari; and Exploring English Vocabulary Learning of Mentally Retarded Students in SekolahLuarBiasa II Yogyakarta by OktaMahendra.

In addition, this research opens the minds and insights of the students from Magisters' Program in English Education to learn one aspect of linguistics in more detail and depth, so that the understanding and importance of applying registers in teaching and learning process can be more realized and understood.

\section{RESEARCH METHODS}

\subsection{Descriptive Qualitative}

Descriptive qualitative approachwas used in conducting this research. According to Milles and Hubberman (1992: 2) maintained that qualitative data tend to be in the form of words than series of number. The object of this research wasthe teachers of mentally retarded students in 7 Sekolah Luar Biasa(SLB) in Yogyakarta in the academic year 2019/2020, which were located on Jalan Kapten Laut Samadikun No.3 Yogyakarta; Jalan Imogiri 224 Yogyakarta; Jalan Wates 147 km.3 Ngestiharjo Kasian Bantul Yogyakarta; Jalan Panembahan Senopati 46 Prawirodirjan Gondomanan Yogyakarta; Jalan Magelang km.17 Margorejo Tempel Sleman Yogyakarta; Candirejo Bokoharjo Prambanan Sleman Yogyakarta; Jalan Plosokuning II Minomartani Ngaglik Sleman Yogyakarta .

Yin (2009: 103) wrote that there are some kinds of data and information collecting technique. The data in this research were collected by observation, interview, and documentation. The teaching and 
learning process of mentally retarded students was observed then the interview was conducted to the teacher for knowing the registers they used. Sugiyono (2008: 329) said the document is a record of events that have already passed in the form of text, images, or monumental works of a person. Therefore, in this research documentation was used to support data.

The data wereanalysed by using descriptive qualitative technique. According to Flick (2013: 6), qualitative data analysis is the classification and interpretation of linguistic (or visual) material to make statements about implicit and explicit dimensions and structures of meaning-making in the material and what is represented in it. Meaning-making can refer to subjective or social meanings. Qualitative data analysis was also applied to discover and describe issues in the field or structures and processes in routines and practices. Thinking critically is needed in the process of data analysis technique in order to get patterns of other explanation forms.

Heidi Dulay, M. Burt, and S. Krashen (1982: 17) say that people cannot learn language without first systematically committing errors. They are four descriptive taxonomies to analyze errors: the linguistic category taxonomy, the communicative effect taxonomy. The linguistic category taxonomy classifies errors based on language components, using linguistic terms, such as classifying errors into morphological and syntactic errors, phonological errors, semantic and lexical errors, and discourse. Every component was divided into smaller classification. The surface strategy taxonomy classifies errors into four categories, namely omission of some required elements, addition of some unnecessary or incorrect element, malformation of elements, and disordering elements. The comparative taxonomy classifies errors into four, namely developmental or intralingua errors, Interlingua errors, ambiguous errors and other errors. The communicative effect taxonomy deals with errors from the perspective of their effect on the listener or reader. It focuses on distinguishing between errors that seem to cause miscommunication.

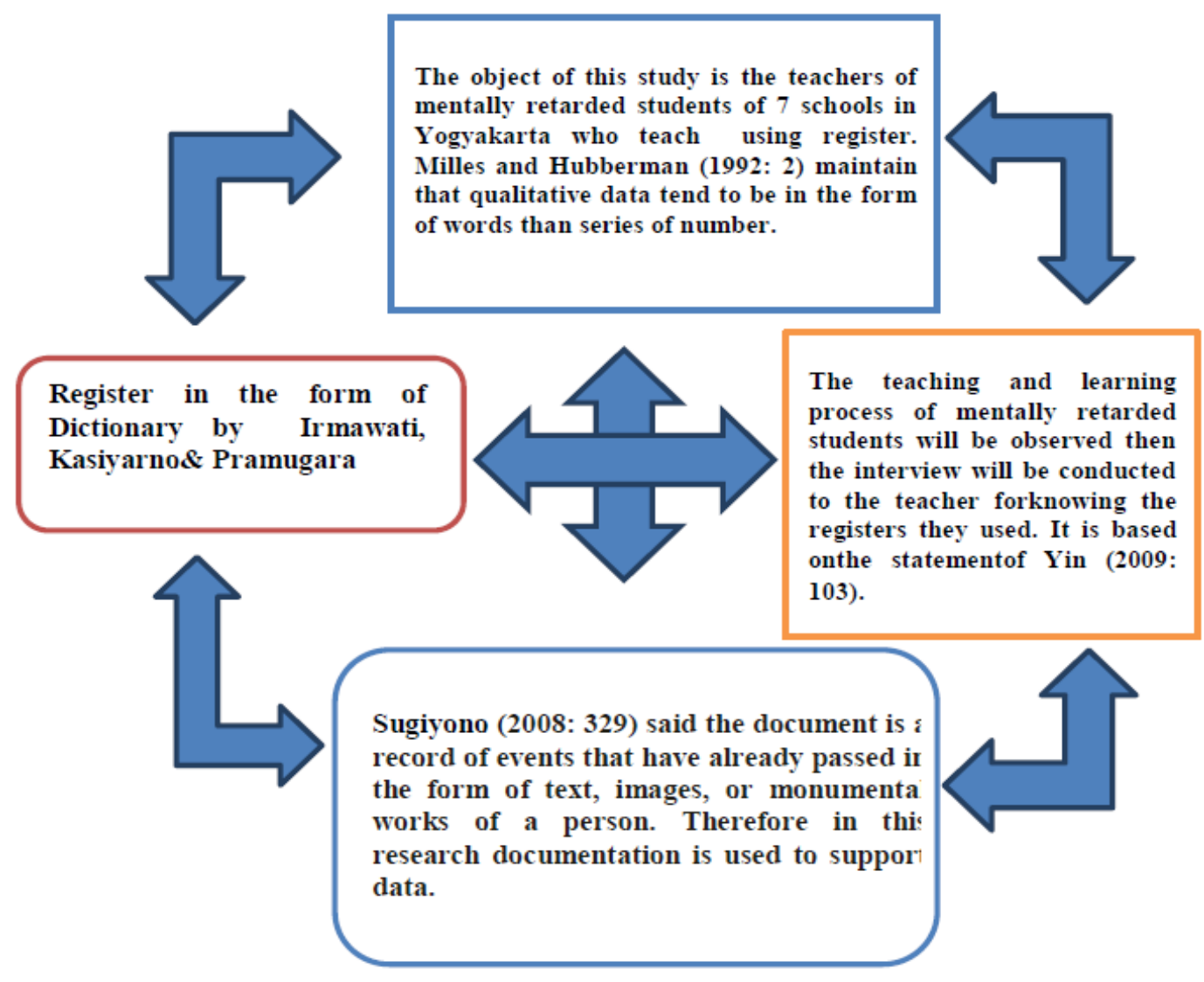

Figure1: Theoretical Paradigm

Taylor states that error analysis is the study and evaluation of uncertainty in measurement (1997: 23). Error analysis is used in this research because error has a positive role in language learning. The design of the research is qualitative study which will be conducted at SLB and others Inclusive schools in the form of descriptive qualitative research design. It aims to explore how teachers of 
mentally retarded students teach language or English and discover the factors that influence them. The clearly and detailed data observation are needed, so the investigation approach design is also used. Beside that interview and document will become the seconder instrument, such as the teacher and school development notes. The data are collected by facing and interacting with the informant directly, giving questionnaires, and doing observation

Those above Research Methodologies can be implemented in the following theoretical paradigm.

\subsection{Conceptual Framework}

The presentation of the research became the system's approach consisting of the input, process, and output to outline the variable and the expected outcome of the study.

Input focused on the result of finding the data of how teachers of mentally retarded students teach using registers as the language used in the teaching learning process. The data were taken from giving questionnaires, interview, and doing observation into seven SekolahLuarBiasa (SLB) in Yogyakarta.

Process shows the data finding through questionnaires, interview, and direct observation. Then the data were classified, categorized and analyzed.

Outputshows some registers that are used by the teachers in the teaching learning process. Those registers are used to compose dictionary which can be used as language for teachers who teach mentally retarded students. It can also be used by the students themselves in order to understand the word which are called register.

Another output is the result of the research which is presented in the seminar and published in the Journal or Proceeding.

The feedback is benefit to be used in modifying the output and also preparing the teaching material that using registers.

The following is the figure of the step of Conceptual Framework in this research:

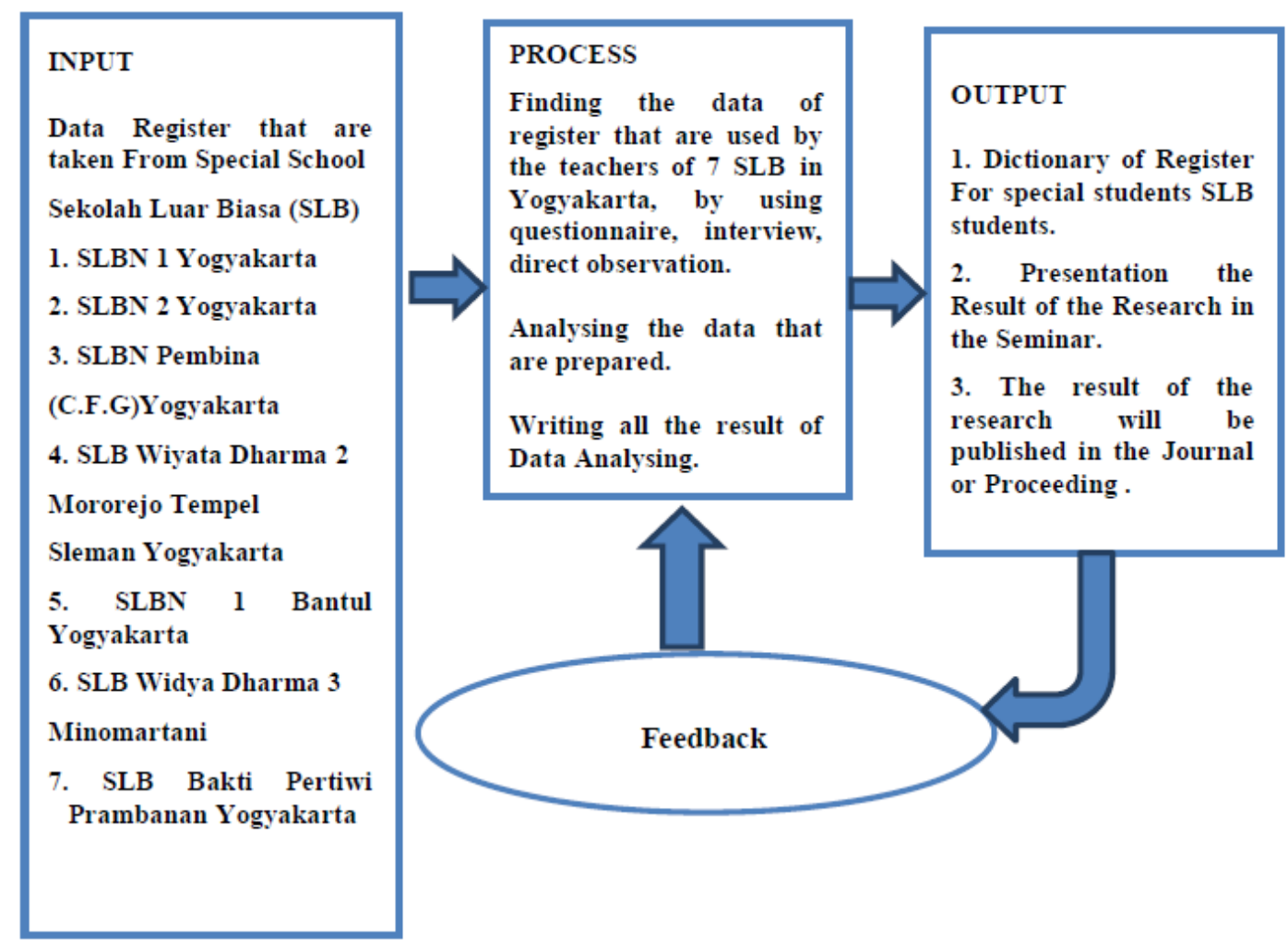

Figure2: Conceptual Framework

\subsection{Data Sources}

Data is as reference in analyse and interpretation due to determine the conclusion of the study or research. Data collection techniques obtained through observation, and interviews. Observations were 
made to obtain a clearer picture of the problem to be examined. The observation stage carried out in this study is as an observation used for data collection as a complement to interview techniques. At the observation stage of the application of learning, the researcher focuses on the observation of aspects of language learning as a speech language in the teaching and learning process. In this application the researcher observes how the teacher applies the results of learning design in mild retardation class using Registers. While the primary data obtained from the interview process. This study uses the type of semi-structured interviews that are included in the in-depth interview category the purpose of the semi-Structured interview is to determine the problem more openly. In this study, the informants were determined purposively by considering that the informants were the ones who knew best.

Researchers conducted interviews directly on the subject, namely first, Learning Vocational School from SLBN 1 Yogyakarta, SLBN 2 Yogyakarta, SLBN Bhakti Pertiwi, SLB 2 Widya Dharma, SLB 3 Widya Dharma, SLB Bakti Pertiwi Prambanan, and SLBN Yogyakarta Guidance. The second interview with the person in charge in the field of curriculum, regarding the curriculum planned for SLB in providing services for children with special needs, especially mild retardation.

Material Gathering Procedures

In doing the analysis, the researchers take the following steps:

- Classifying the data which can be categorized as the register.

- Analysing the data by identifying the word formation of the words and phrases form.

- Analysing the context of data to identify the differences between the lexical meaning and contextual meaning.

- Drawing the conclusion and suggestion based on the data analysis.

- Constructing the output of the study.

\subsection{Data Collecting Technique and Instruments}

There are some kinds of data and information collecting technique. At least could be three kind of ways that may be used to collect data and information to support the research, especially research conducted in qualitative types. They are as the following: 1. Observation, 2. Interview, and 3. Document.

Based on the explanation above, then some instruments are decided to use some data collecting technique, and those are mentioned below:

\subsubsection{Observation}

As a qualitative research method, observation is a complex research method because it often requires the researcher to play a number of roles and to use a number of techniques, including the researcher's five senses, to collect data. In addition, despite the level of involvement with the study group, the researcher must always remember the primary role as a researcher and remain detached enough to collect and analyse data relevant to the problem under investigation. Observation is as a technique of data accumulation which has specific characteristics that will be compared with another technique, it is interview and questioner. Interview and questioner are always communication with the peoples. So, observation not only for people, but also for another object. Observation can be divided into two parts. The first is participant observation and second is nonparticipant observation. In this case, the researcher used participant observation. In this research, the learning activity of mentally retarded students are observed in the class, how the teacher teaches and students learn English as their foreign language as in Indonesia. So, hopefully the results of the data will be accurate and complete.

\subsubsection{Interview}

Interview is an attempt to collect information by asking a number of questions answer orally for verbally anyway. The main characteristic of the interview is in direct contact with the face to face between the information seeker (interviewer or informant hunter) with resources interviewee. Interview is used as data collecting technique if the researcher wants to do the introduction study first to find the research problem, and if the researcher wants to know about the respondents. In this interview there are 10 questions. 
Interview that is done in this study. The main focuses of the interview are about difficulties which faced by the student, the factors, how the students learn Language or English and how the way the teacher solve it.

\subsubsection{Document}

Documentary method is one method of data collection used in social research methodology to explore historical data. The document is a record of events that have already passed in the form of text, images, or monumental works of a person.

Based on statements above the researcher used the second statement to support this research. In this research the researcher uses the document to collect the data. The document can be text or images form. The steps are:

- Participant observation will be done before the interview; the researcher looks the data from the teacher.

- After that, the teacher will be interviewed.

- This is recorded when the students are being interviewed and make documentation. The document can form of text or images.

- Another documents will support are attendance list, book, list of the score, students personal notes by the teacher, lesson plans, syllabus, and curriculum references.

\subsection{Research Instrument}

There are some types of data collecting technique that can be used as following step in making instrument to collect the data. In this case, non-participative observer is applied to take main data in class activity, since in this research. Means, research data collecting is done mainly by interview the teachers and family and observation sheet based on some questions designed. Especially by holding an interview and observation, there will be specified questions related to students' in learning Language, especially in learning English.

\subsection{Data Analysis Technique}

Data Analysis is the process of organizing the data in order to gain regularly of the pattern and form of the research. The term interpretation can be defined as a procedure of giving meaning in the result of the analytic process. Qualitative data analysis is the classification and interpretation of linguistic (or visual) material to make statements about implicit and explicit dimensions and structures of meaningmaking in the material and what is represented in it. Meaning-making can refer to subjective or social meanings. Qualitative data analysis is also applied to discover and describe issues in the field or structures and processes in routines and practices. In the process of data analysis technique, the researcher needs to think critically. Data Analysis is needed in a research as a process for organizing the data in order to get patterns of other explanation forms. Data Analysis qualitative is case study about social reality, loyal at data empiric and having an orientation on paradigm research. Data Analysis is process to find and manages systematically the data from interview, field note, and documentation, with way organize the data, clarify into units, arrange the design, chose the important thing which will learned, and make a conclusion, so easy to understand for oneself or other people. Firstly, the researchers do to organize the data, after that clarify the data into units, then arrange them into the design and the result of this research.

\section{RESEARCH RESUlt AND OUTPUT ACHIEVED}

The data of this research are taken from 49 teachers of Mentally Retarded Students in Seven Extraordinary Schools (SLB) in Yogyakarta. It can be described as follows:

Table3: The Data of Questionnaire, Interview, and Observation

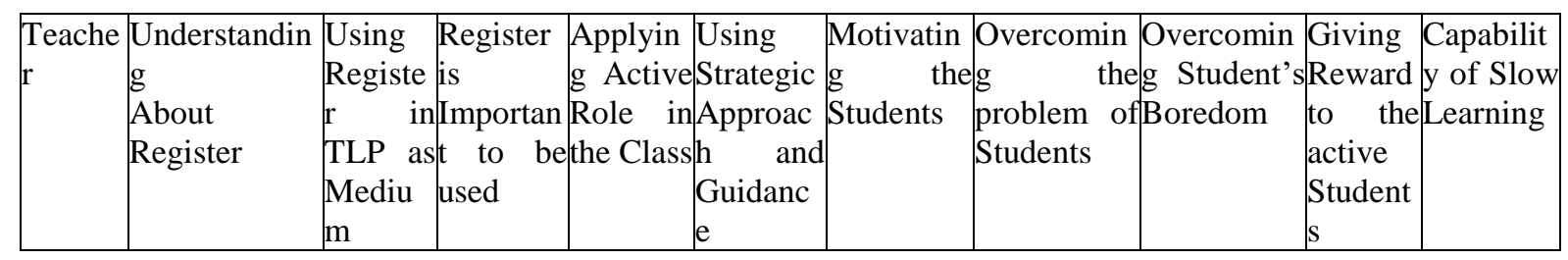




\begin{tabular}{|c|c|c|c|c|c|c|c|c|c|c|}
\hline 1. & $\mathrm{~V}$ & V & $\mathrm{V}$ & $\mathrm{V}$ & $\mathrm{V}$ & $\mathrm{V}$ & $\mathrm{V}$ & $\mathrm{V}$ & $\mathrm{V}$ & $\mathrm{V}$ \\
\hline 2. & & $\mathrm{~V}$ & & $\mathrm{~V}$ & $\mathrm{~V}$ & $\mathrm{~V}$ & $\mathrm{~V}$ & $\mathrm{~V}$ & $\mathrm{~V}$ & \\
\hline 3. & $\mathrm{~V}$ & $\mathrm{~V}$ & & $\mathrm{~V}$ & $\mathrm{~V}$ & & $\mathrm{~V}$ & $\mathrm{~V}$ & & $\mathrm{~V}$ \\
\hline 4. & $\mathrm{~V}$ & V & V & $\mathrm{V}$ & $\mathrm{V}$ & $\mathrm{V}$ & V & & $\mathrm{V}$ & \\
\hline 5. & $\mathrm{~V}$ & $\mathrm{~V}$ & $\mathrm{~V}$ & & $\mathrm{~V}$ & & $\mathrm{~V}$ & $\mathrm{~V}$ & $\mathrm{~V}$ & $\mathrm{~V}$ \\
\hline 6. & & $\mathrm{~V}$ & $\mathrm{~V}$ & $\mathrm{~V}$ & $\mathrm{~V}$ & $\mathrm{~V}$ & $\mathrm{~V}$ & $\mathrm{~V}$ & $\mathrm{~V}$ & \\
\hline 7. & $\mathrm{~V}$ & V & $\mathrm{V}$ & $\mathrm{V}$ & & V & V & $\mathrm{V}$ & $\mathrm{V}$ & $\mathrm{V}$ \\
\hline 8. & $\mathrm{~V}$ & $\mathrm{~V}$ & $\mathrm{~V}$ & $\mathrm{~V}$ & $\mathrm{~V}$ & $\mathrm{~V}$ & $\mathrm{~V}$ & $\mathrm{~V}$ & & $\mathrm{~V}$ \\
\hline 9. & & & & $\mathrm{~V}$ & $\mathrm{~V}$ & $\mathrm{~V}$ & $\mathrm{~V}$ & $\mathrm{~V}$ & $\mathrm{~V}$ & \\
\hline 10. & $\mathrm{~V}$ & & V & $\mathrm{V}$ & $\mathrm{V}$ & V & V & $\mathrm{V}$ & V & $\mathrm{V}$ \\
\hline 11. & & $\mathrm{~V}$ & $\mathrm{~V}$ & D & $\mathrm{V}$ & $\mathrm{V}$ & & $\mathrm{V}$ & $\mathrm{V}$ & \\
\hline 12. & $\mathrm{~V}$ & $\mathrm{~V}$ & $\mathrm{~V}$ & $\mathrm{~V}$ & $\mathrm{~V}$ & $\mathrm{~V}$ & $\mathrm{~V}$ & $\mathrm{~V}$ & $\mathrm{~V}$ & $\mathrm{~V}$ \\
\hline 13. & & V & V & $\mathrm{V}$ & $\mathrm{V}$ & V & & $\mathrm{V}$ & & $\mathrm{V}$ \\
\hline 14. & $\mathrm{~V}$ & $\mathrm{~V}$ & $\mathrm{~V}$ & $\mathrm{~V}$ & $\mathrm{~V}$ & $\mathrm{~V}$ & $\mathrm{~V}$ & $\mathrm{~V}$ & $\mathrm{~V}$ & $\mathrm{~V}$ \\
\hline 15. & & $\mathrm{~V}$ & $\mathrm{~V}$ & $\mathrm{~V}$ & $\mathrm{~V}$ & $\mathrm{~V}$ & $\mathrm{~V}$ & $\mathrm{~V}$ & & $\mathrm{~V}$ \\
\hline 16. & & $\mathrm{~V}$ & & $\mathrm{~V}$ & $\mathrm{~V}$ & $\mathrm{~V}$ & & & $\mathrm{~V}$ & \\
\hline 17. & $\mathrm{~V}$ & $\mathrm{~V}$ & $\mathrm{~V}$ & $\mathrm{~V}$ & $\mathrm{~V}$ & $\mathrm{~V}$ & $\mathrm{~V}$ & $\mathrm{~V}$ & $\mathrm{~V}$ & $\mathrm{~V}$ \\
\hline 18. & $\mathrm{~V}$ & $\mathrm{~V}$ & $\mathrm{~V}$ & T & $\mathrm{V}$ & ] & $\mathrm{V}$ & $\mathrm{V}$ & $\mathrm{V}$ & $\mathrm{V}$ \\
\hline 19. & & $\mathrm{~V}$ & & $\mathrm{~V}$ & $\mathrm{~V}$ & $\mathrm{~V}$ & & $\mathrm{~V}$ & & $\mathrm{~V}$ \\
\hline 20. & & & $\mathrm{~V}$ & $\mathrm{~V}$ & $\mathrm{~V}$ & $\mathrm{~V}$ & $\mathrm{~V}$ & $\mathrm{~V}$ & $\mathrm{~V}$ & $\mathrm{~V}$ \\
\hline 22. & $\mathrm{~V}$ & $\mathrm{~V}$ & $\mathrm{~V}$ & $\mathrm{~V}$ & $\mathrm{~V}$ & $\mathrm{~V}$ & $\mathrm{~V}$ & $\mathrm{~V}$ & $\mathrm{~V}$ & $\mathrm{~V}$ \\
\hline 22. & & V & & $\mathrm{V}$ & $\mathrm{V}$ & V & & $\mathrm{V}$ & & \\
\hline 23. & & $\mathrm{~V}$ & $\mathrm{~V}$ & $\mathrm{~V}$ & $\mathrm{~V}$ & $\mathrm{~V}$ & $\mathrm{~V}$ & $\mathrm{~V}$ & $\mathrm{~V}$ & $\mathrm{~V}$ \\
\hline 22. & $\mathrm{~V}$ & $\mathrm{~V}$ & $\mathrm{~V}$ & $\mathrm{~V}$ & $\mathrm{~V}$ & $\mathrm{~V}$ & $\mathrm{~V}$ & $\mathrm{~V}$ & $\mathrm{~V}$ & $\mathrm{~V}$ \\
\hline 25. & $\mathrm{~V}$ & $\mathrm{~V}$ & V & $\mathrm{V}$ & $\mathrm{V}$ & $\mathrm{V}$ & $\mathrm{V}$ & $\mathrm{V}$ & $\mathrm{V}$ & $\mathrm{V}$ \\
\hline 26. & & $\mathrm{~V}$ & & $\mathrm{~V}$ & | & $\mathrm{V}$ & & $\mathrm{V}$ & $\mathrm{V}$ & \\
\hline 22. & & $\mathrm{~V}$ & 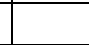 & $\mathrm{V}$ & $\mathrm{V}$ & $\mathrm{V}$ & $\mathrm{V}$ & $\mathrm{V}$ & $\mathrm{V}$ & $\mathrm{V}$ \\
\hline 28. & $\mathrm{~V}$ & $\mathrm{~V}$ & V & $\mathrm{V}$ & $\mathrm{V}$ & $\mathrm{V}$ & $\mathrm{V}$ & $\mathrm{V}$ & $\mathrm{V}$ & $\mathrm{V}$ \\
\hline 29. & $\mathrm{~V}$ & $\mathrm{~V}$ & $\mathrm{~V}$ & $\mathrm{~V}$ & $\mathrm{~V}$ & $\mathrm{~V}$ & $\mathrm{~V}$ & $\mathrm{~V}$ & $\mathrm{~V}$ & $\mathrm{~V}$ \\
\hline 30. & $\mathrm{~V}$ & $\mathrm{~V}$ & $\mathrm{~V}$ & $\mathrm{~V}$ & $\mathrm{~V}$ & $\mathrm{~V}$ & $\mathrm{~V}$ & $\mathrm{~V}$ & $\mathrm{~V}$ & $\mathrm{~V}$ \\
\hline 33. & & $\mathrm{~V}$ & & $\mathrm{~V}$ & & $\mathrm{~V}$ & $\mathrm{~V}$ & & $\mathrm{~V}$ & \\
\hline 32. & 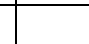 & 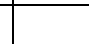 & 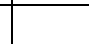 & 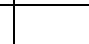 & $\mathrm{V}$ & 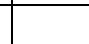 & $\mathrm{V}$ & 7 & $\mathrm{~V}$ & $\mathrm{~V}$ \\
\hline 33. & $\mathrm{~V}$ & $\mathrm{~V}$ & $\mathrm{~V}$ & $\mathrm{~V}$ & $\mathrm{~V}$ & $\mathrm{~V}$ & $\mathrm{~V}$ & $\mathrm{~V}$ & $\mathrm{~V}$ & $\mathrm{~V}$ \\
\hline 34. & $\mathrm{~V}$ & $\mathrm{~V}$ & $\mathrm{~V}$ & $\mathrm{~V}$ & $\mathrm{~V}$ & $\mathrm{~V}$ & $\mathrm{~V}$ & $\mathrm{~V}$ & $\mathrm{~V}$ & $\mathrm{~V}$ \\
\hline 35. & $\mathrm{~V}$ & 5 & & $\mathrm{~V}$ & | & $\mathrm{V}$ & & $\mathrm{V}$ & & $\mathrm{V}$ \\
\hline 36. & & $\mathrm{~V}$ & & $\mathrm{~V}$ & $\mathrm{~V}$ & & $\mathrm{~V}$ & & $\mathrm{~V}$ & \\
\hline 33. & $\mathrm{~V}$ & $\mathrm{~V}$ & V & $\mathrm{V}$ & $\mathrm{V}$ & $\mathrm{V}$ & $\mathrm{V}$ & $\mathrm{V}$ & $\mathrm{V}$ & $\mathrm{V}$ \\
\hline 38. & & & $\mathrm{~V}$ & & $\mathrm{~V}$ & & $\mathrm{~V}$ & & $\mathrm{~V}$ & $\mathrm{~V}$ \\
\hline 39. & $\mathrm{~V}$ & $\mathrm{~V}$ & $\mathrm{~V}$ & $\mathrm{~V}$ & $\mathrm{~V}$ & $\mathrm{~V}$ & $\mathrm{~V}$ & $\mathrm{~V}$ & $\mathrm{~V}$ & $\mathrm{~V}$ \\
\hline 40. & & $\mathrm{~V}$ & & $\mathrm{~V}$ & $\mathrm{~V}$ & & $\mathrm{~V}$ & & $\mathrm{~V}$ & $\mathrm{~V}$ \\
\hline 44. & $\mathrm{~V}$ & $\mathrm{~V}$ & $\mathrm{~V}$ & $\mathrm{~V}$ & $\mathrm{~V}$ & $\mathrm{~V}$ & $\mathrm{~V}$ & $\mathrm{~V}$ & $\mathrm{~V}$ & $\mathrm{~V}$ \\
\hline 42. & $\mathrm{~V}$ & $\mathrm{~V}$ & $\mathrm{~V}$ & $\mathrm{~V}$ & $\mathrm{~V}$ & $\mathrm{~V}$ & $\mathrm{~V}$ & $\mathrm{~V}$ & $\mathrm{~V}$ & $\mathrm{~V}$ \\
\hline 4 & & V & & $\mathrm{V}$ & & $\mathrm{V}$ & & $\mathrm{V}$ & & $\mathrm{V}$ \\
\hline 44. & & & & & $\mathrm{~V}$ & $\mathrm{~V}$ & $\mathrm{~V}$ & $\mathrm{~V}$ & $\mathrm{~V}$ & $\mathrm{~V}$ \\
\hline 45. & $\mathrm{~V}$ & $\mathrm{~V}$ & $\mathrm{~V}$ & $\mathrm{~V}$ & $\mathrm{~V}$ & $\mathrm{~V}$ & $\mathrm{~V}$ & $\mathrm{~V}$ & $\mathrm{~V}$ & $\mathrm{~V}$ \\
\hline 46. & $\mathrm{~V}$ & $\mathrm{~V}$ & $\mathrm{~V}$ & $\mathrm{~V}$ & $\mathrm{~V}$ & $\mathrm{~V}$ & $\mathrm{~V}$ & $\mathrm{~V}$ & & $\mathrm{~V}$ \\
\hline 44. & $\mathrm{~V}$ & $\mathrm{~V}$ & $\mathrm{~V}$ & $\mathrm{~V}$ & $\mathrm{~V}$ & $\mathrm{~V}$ & $\mathrm{~V}$ & $\mathrm{~V}$ & $\mathrm{~V}$ & $\mathrm{~V}$ \\
\hline 48. & & $\mathrm{~V}$ & & $\mathrm{~V}$ & & $\mathrm{~V}$ & $\mathrm{~V}$ & $\mathrm{~V}$ & $\mathrm{~V}$ & \\
\hline 49 & $\mathrm{~V}$ & $\mathrm{~V}$ & $\mathrm{~V}$ & $\mathrm{~V}$ & $\mathrm{~V}$ & $\mathrm{~V}$ & $\mathrm{~V}$ & $\mathrm{~V}$ & $\mathrm{~V}$ & V \\
\hline Total & 28 & 42 & 33 & 43 & 43 & 42 & 41 & 42 & 40 & 38 \\
\hline Percen & 57.1 & 85.7 & 67.3 & 87.8 & 87.8 & 85.7 & 83.7 & 85.7 & 81.6 & 77.6 \\
\hline
\end{tabular}

Terms:

TLP = Teaching Learning Process

SLB = SekolahLuarBiasa (Extraordinary Sc

From the data that are collected and analysed, the results of the teacher's answers can be categorized into 10 points, namely:

- Understanding About the Register, there are 28 teachers out of 49 , meaning $57.1 \%$ who stated that understanding the register as part of linguistics is good as a language of instruction in teaching. 
While other teachers are not yet aware of the Register that can be used in teaching and learning process. It can even be said that they just knew the term Register.

- Using the Register in TLP as Medium, there are 42 (85.7\%) teachers who have used the Register in the teaching and learning process, but they have only just realized that what they use as learning media is the Register.

- The Register is Important to be used, $33(67.3 \%)$ teachers stated that the Register was important to use because it facilitated student understanding. The register used is in word form.

- Applying Active Role in the Class, 43 out of 49 teachers (87.8\%) applied their active role in classroom learning.

- Using Strategic Approach and Guidance, 43 out of 49 teachers (87.8\%) use a strategy of approaching and mentoring students in TLP. The strategy is based on the situation and condition of the students.

- Motivating the Students, the hard-working of SLB (Extraordinary Schools) teachers is to motivate students to be able to follow lessons and activities in their schools to improve student selfdevelopment. The results of data processing showed that $85.7 \%$ of teachers carried out this activity.

- Overcoming the problem of Students, the teacher tries to help students who have problems in a variety of ways and strategies such as personal approaches, ongoing consultations, guiding students and other efforts aimed at helping students overcome their problems. This is corroborated by the teacher's statement found from the results of data analysis, which is as much as $83.7 \%$ giving this treatment.

- Overcoming Student's Boredom, the most difficult thing for teachers to deal with when teaching SLB students is that if students experience boredom then there is no more seriousness of students that can be expected, especially in terms of concentration in TLP. This is proven by the existence of $85.7 \%$ of teachers who stated this.

- Giving Reward to the active Students, the teacher gives rewards to students who actively participate in the lesson. It is also a form of motivation to arouse learning enthusiasm and students' desire for science. From $100 \%$ of teachers in this research, $81.6 \%$ gave a reward to their students.

- Capability of Slow Learning, making obstacles in learning, especially in language learning. This is proven by the teacher's answer which is $77.6 \%$ who states that.

The findings targeted in this study are how educators for students with mental retardation use registers in teaching and interaction with their students, so that the message delivered will be easily received and further strengthen the relationship between students and all school members. In the end, the register used will become a reference dictionary that is useful in recognizing, understanding and establishing communication for the general public and the public with mental auction, so that this sustainable-based product will have tangible benefits for the life of the nation.

Successful outcomes in this study are:

- Asian Journal of TEFL Scopus index

- Scientific Publication of an Accredited National Journal (Cakrawalapendidikan)The paper sent was revised in its issue, Journal attached https://journal.uny.ac.id/index.php/cp

- Proceedings in international scientific meetings or Conference

- The Output Model to be addressed is in the form of a register dictionary for the mental retardation student environment which can be used as a reference for students, teachers and the wider community with ISBN and Scopus indexed standards. The design obtained from this study can be applied and developed for the development of a Dictionary of register 2.0.

The dictionary of register for learners with special needs can be recognized and endorsed as a tool in the language learning process for mentally retarded students who have special needs. In addition, this 
registers' dictionary will help teachers and mentally retarded students to facilitate language learning and can also become references to increase students' enthusiasm and achievement in language learning.

In addition, from the research that has been carried out, it can be created a number of research titles that discuss about Register and other linguistic aspects to be used as further research project by creating new titles under this title, by taking another themes and a new point of view which will be discussed as a research for Master's Degree students in completing their studies.

\section{CONCLUSIONS AND SugGeSTIONS}

\subsection{Conclusion}

Based on the results of research and discussion that has been described, it can be concluded that the implementation of learning for mentally retarded students is seen from several aspects, namely:

\subsubsection{Difficult to Learn}

Mentally disabled students find it difficult to learn. This difficulty is caused by their mental retardation. Barriers and Solutions for learning in SLB in Yogyakarta, there are several obstacles namely student barriers, barriers to student concentration, barriers to learning resources, barriers to learning facilities and infrastructure. These obstacles can be overcome by the teacher accompanying them, directing their students to always concentrate. These constraints are caused by the lack of ability of students who cannot be forced due to the low level of intelligence in retarded students.

\subsubsection{Understanding the Term Register}

The teacher's understanding of the term Register is still lacking, as evidenced from 100\%, there are only $57.1 \%$ who answered that they already know the Register as one part of linguistics. The register can be used as a speech tool to convey messages in communication.

\subsubsection{Unwittingly Used the Register}

Most teachers have unwittingly used the Register in the Teaching and Learning Process. This is evidenced by the teacher's answers to the questions and the results of the researchers' observations, which is $85.7 \%$ of $100 \%$ of teachers who use the Register as a learning tool.

\subsubsection{Intervention Steps are Needed}

Intervention steps are needed to increase student mastery in learning. The register dictionary is one of the best interventions for action besides the use of audio-visual material that is supported by technology.

\subsection{Suggestion}

Based on the conclusions, the researchers convey the following suggestions.

\subsubsection{School and Learning Process}

School is needed, to achieve the expected goals, then to all parties involved in the school to help the learning process for students with intellectual disabilities. The headmaster is willing to provide books for supporting packages for mentally retarded students. In addition, the principal should also provide infrastructure that can help class teachers in the teaching and learning process.

\subsubsection{Parents' Involvement}

Required to involve parents, family members, private organizations and other professionals to support the education of mentally retarded students outside of school.

\subsubsection{Intervention Measures}

Intervention measures must be adopted by the teacher according to the student's ability, level and entry-level understanding. As well as involving retarded students in study groups in the class will be very helpful in a variety of methods as well as in improving their social skills.

\subsubsection{Learning Materials}

The use of learning material is highly recommended to produce changes in the ability of students to use and understand words in accordance with the intent and purpose. This dictionary can be used by teachers and students who want to learn with less supervision. 


\subsubsection{Learning Media}

In learning, teachers should use the learning media more often. The learning media used must be concrete, easy to use and familiar with retarded students. It is because students with intellectual disabilities have difficulty in abstract thinking. It is Expected for teachers who are capable of learning with students with special needs to get briefing first. So, the implementation of learning can run optimally as it should.

\section{REFERENCES}

[1] Algozzine, Bob danYsseldyke, Jim. 2006. Teaching Students With Mental Retardation A Practical Guide for Every Teacher. California: Corwin Press.

[2] Biber,Douglas \& Conrad, Susan. 2009. Register, Genre, and Style. NewYork,NY: Cambridge University Press.

[3] Binet, A., 1949. Modern Ideas About Children. Menlo Park, CA: Suzanne Heisler.

[4] Dulay,Heidi,M.Burt,andS.Krashen. 1982.Language Two.Oxford:Oxford University Press.

[5] EndangRochyadi. 2005. Pengembangan Program Pembelajaran Individual BagiAnakTunagrahita. Jakarta: Depdiknas.

[6] Flick,Uwe.2013.The Sage Handbook of Qualitative Data Analysis.London: Sage.

[7] Hainstock, E. G. 2002. Montessori UntukAnakPrasekolah. Jakarta: PustakaDelaprasta.

[8] Heber, R., 1959. A Manual on Terminology and Classification in Mental Retardation. American Journal of Mental Deficiency, 64(2): 1-111.

[9] Heward, W.L., 2003. Exceptional Children, An Introduction To Special Education. London: Pearson Education.

[10] Holmes, Janet. 1992. An Introduction to Linguistic (Second Edition). UK: Pearson Education Limited.

[11] Hudson,R.A.1991.Sociolinguistic.Cambridge:Cambridge University Press.

[12] Internet sources: https://aaidd.org/intellectual-disability

[13] -----. 2019. https://journal.uny.ac.id/index.php/cp

[14] Katamba, Francis. 1993. Morphology: Modern Linguistics Series. London: The Macmillan Press Ltd.

[15] Kaplan, H.l. and B.J. Sadock, 1998. Kaplan And Sadock's Synopsis of Psychiatry: BehaviouralSciences, Clinical Psychiatry. Michigan: Williams and Wilkins..

[16] Krapez, S. 2010. Second Language Comprehension And Acquisition In Mentally Disabled ChildrenIllusion Or Reality. IBS Newsletter Portocevalec.

[17] Miles,B.Mathew and Michael Huberman.1992.Analisis Data KualitatifBukuSumberTentangMetodemetodeBaru.Jakarta:UIP Press.

[18] Muhammad Efendi. 2006. PengantarPsikopedagogikAnakBerkelainan. Jakarta: PT BumiAksara.

[19] Mumpuniarti. 2007.PembelajaranAkademikBagiTunagrahita. BukuPeganganKuliahJurusan PLB-FIPUNY. Yogyakarta: FIP-UNY.

[20] NunungApriyanto. 2012. SelukBelukTunagrahita\&StrategiPembelajarannya. Yogyakarta: Javalitera

[21] Pocock, S., n.d. Teaching Academics To Students With Mental Retardation. Williamsburg, Virginia: The College of William and Mary.

[22] Procter, Paul (Ed). 2008. Cambridge International Dictionary of English. Oxford: Cambridge University Press Publishers Ltd.

[23] Rosenthal,R.\&Jacobson,L.1966.Teachers'Expectancies.Determinants of Pupils'IQ Gains. Psychological Reports, 2019, 115-118. Retrieved from http://dx.doi.org/10.2466/pr0.1966.19.1.115 Accessed On August 24, 2018at6.40 PM.

[24] Sugiyono.2008. MetodePenelitian KuantitatifKualitatifdan $R \& D$. Bandung: Alfabeta.

[25] Smith,David. 2009. Inklusi: Sekolah Ramah untukSemua, terjemahanEnrica Denis. Bandung: Nuansa.

[26] Taylor,J.R.1997.An Introduction to Error Analysis: the Study of Uncertainties in Physical Measurements.2nd Edition. Colorado: University Science Book.

[27] Tin Suharmini. 2009.PsikologiAnakBerkebutuhanKhusus. Yogyakarta: Kanwa Publisher.

[28] Trent, J.W. 1995. Inventing the Feeble Mind: A History of Mental Retardation in The United States (Medicine and Society). California: University of California Press.

[29] Wantah, Maria J. 2007. PengembanganKemandirianAnakTunagrahitaMampuLatih. Bandung: Departemen PendidikanNasional. 
[30] Wardani, IGAK. 2011. Pengantar Pendidikan LuarBiasa. Jakarta: Universitas Terbuka.

[31] Wardaugh,Ronald.1992.An Introduction to Sociolinguistics.UK:Blackwell.

[32] Yin, R. K. 2009. Case Study Research: Design and Method (4rd ed.). California: Sage Publications,Inc.

[33] Yule, George. 2006. The Study of Language (3th Edition). Cambridge: Cambridge UniversityPress.

[34] YustinusSemiun. 2006. Kesehatan Mental 2. Yogyakarta: PenerbitKanisius.

Citation: Noer DoddyIrmawati, et.al. Exploring Registers Used by the Teachers of Mentally Retarded Students to Further Create a Dictionary. "International Journal on Studies in English Language and Literature (IJSELL), vol 7, no. 12, 2019, pp. 43-54. doi: http://dx.doi.org/10.20431/2347-3134.0712003.

Copyright: () 2019 Authors. This is an open-access article distributed under the terms of the Creative Commons Attribution License, which permits unrestricted use, distribution, and reproduction in any medium, provided the original author and source are credited. 